\title{
SURFACE POTENTIAL OF DIAMOND AND DIAMOND-LIKE CARBON THIN FILMS ON Si SUBSTRATE*
}

\author{
M. Dłużniewski ${ }^{\text {a }}$, T. Lozovski $^{\text {b }}$, R. Pūras ${ }^{\text {b }}$, and S. Sakalauskas ${ }^{\text {b }}$ \\ a Institute of Physics, Technical University of Lodz, Wolczanska 219, 93-005 Lodz, Poland \\ ${ }^{\mathrm{b}}$ Vilnius University, Saulètekio 9, LT-10222 Vilnius, Lithuania \\ E-mail: tadeusas.lozovskis@ff.vu.lt
}

Received 13 December 2005

\begin{abstract}
Semiconductor films are increasingly applied for cathodes of autoelectronic emission. In the case of autoelectronic emission the cathode heats itself, therefore the wide band gap semiconductors, such as diamond films, are more suitable for cathodes. Moreover, considering high thermal conduction of diamond films, it is easy to optimize the process of autoelectronic emission. Primary experimental results regarding the investigation of the surface electric potential of diamond thin films and diamondlike carbon (DLC) thin films are presented in the paper. The films, intended for autoelectronic emission cathodes, were deposited on differently processed silicon substrate. Values of electron work function, as well as unambiguously related to it surface electric potential distribution, were examined by contactless Kelvin-Zisman method.
\end{abstract}

Keywords: thin films, diamond, diamond-like carbon, surface electric potential

PACS: $81.05 . \mathrm{Uw}$

\section{Introduction}

Field emission from clean metal surfaces takes place at surface field strengths of the order of $\sim 10^{9} \mathrm{~V} \cdot \mathrm{m}^{-1}$. As a result, for decades field emission was believed to be a property of sharp tips where the macroscopic field could be magnified up to a desired level. This philosophy has dominated the development of field emission electron sources until the last ten years. Until relatively recently, work to improve the performance of tips has been directed towards tips shape and work function. Sharper tips are more sensitive to damage by ions or ohmic heating and nature abhors a low work function in the same way as it does a vacuum.

In the late 80's field emission from planar diamondlike and diamond film surfaces was demonstrated at reasonable macroscopic fields stimulating research into a new class of broad-area electron sources. It was initially believed that broad-area field emission was a special property of diamond films, because some crystal planes when terminated with hydrogen have a negative electron affinity. However, looking back it is clear that in fact it is a general property of thin wide band gap (i. e. insulating) layers on conducting substrates. More-

\footnotetext{
${ }^{*}$ The report presented at the 36th Lithuanian National Physics Conference, 16-18 June 2005, Vilnius, Lithuania.
}

over, although negative electron affinity helps, it is by no means an essential condition for broad-area emission.

Over the past 15 years it has become obvious that the earlier concern about surface properties (i. e. electron affinity) was misplaced and that the critical step, in general, is the injection of electrons into the conduction band of the insulator. Defects or insulator doping enable the formation of a Schottky barrier, which makes this injection possible by tunnelling, despite band offsets. The importance of this cannot be overstressed since it moves the critical area away from the solidvacuum interface, where it can be affected by residual gases and ions, to the protected conductor-insulator interface. As a result, such emitters are more tolerant of poor vacuum conditions than tips. If a negative electron affinity surface exists, electrons injected into the conduction band will be able to leave the surface.

\section{Samples and their growth technology}

Diamond films were grown on silicon substrates by the hot filament chemical vapour deposition (HF CVD) method [1]. The method is simple and inexpensive. Hot filament usually operates near to substrate, therefore it is simple to control the substrate temperature, but 
different diamond structures with many defects grow due to irregular temperature distribution. In order to enhance diamond nucleation density, the standard procedure was performed, i.e. the substrate surface was polished mechanically and then cleaned in acetone, methanol, and distilled water. Mixture of either acetylene or methanol with hydrogen was used for deposition process. Content of acetylene was $1 \%$ (specimen $A 1$ ) or 3\% (specimen $A 2$ ) at growing one group of specimens. The flow rate was $2.5 \mathrm{~cm}^{3} / \mathrm{s}$ and the gas pressure was $5.5 \cdot 10^{3} \mathrm{~Pa}$. Second group of specimens was grown from mixture of methanol and hydrogen: specimen $B 1-1 \%$ of methanol, gas pressure of $5.5 \cdot 10^{3} \mathrm{~Pa}$, film thickness of $0.5 \mu \mathrm{m}$ on $n$-type $\mathrm{Si}\langle 111\rangle$, doped with P, specific resistance $<0.002 \Omega \cdot \mathrm{cm}$; specimen $B 2-1 \%$ of methanol, gas pressure of $5 \cdot 10^{3} \mathrm{~Pa}$, film thickness of $1.23 \mu \mathrm{m}$ on the same substrate; specimen $B 3-1.5 \%$ of methanol, gas pressure of $6 \cdot 10^{3} \mathrm{~Pa}$, film thickness of $1.42 \mu \mathrm{m}$ on $n$-type $\mathrm{Si}\langle 111\rangle$, doped with $\mathrm{Sb}$, specific resistance of $0.002-0.023 \Omega \cdot \mathrm{cm}$. The tungsten filament operated at $2200^{\circ} \mathrm{C}$ and was placed $8 \mathrm{~mm}$ above the substrate. The temperature of substrate was about $750{ }^{\circ} \mathrm{C}$. The details of the system used and typical deposition conditions of large-grain and small-grain diamond films were described elsewhere [1].

The DLC (diamond-like carbon) thin films were prepared by radio frequency $(13.56 \mathrm{MHz})$ chemical vapour deposition (RF CVD). The method is complicated due to many related parameters, but in optimal conditions high quality films can be grown on large areas. Films under investigation were grown from methane at a pressure of $26 \mathrm{~Pa}$ on $n$-type $\mathrm{Si}\langle 111\rangle$ with different roughness of surface, doped with $\mathrm{Sb}$, and had specific resistance of $0.015-0.023 \Omega \cdot \mathrm{cm}$. The applied negative self-bias voltage, which depended on the discharge power, was from -60 to $-300 \mathrm{~V}$. Two different films $(C 1)$ grown on monocrystalline Si with $20 \mathrm{~nm}$ and $60 \mathrm{~nm}$ thicknesses were investigated. Next, two films (C2) of different thicknesses (20 nm and $60 \mathrm{~nm})$ were grown on $\mathrm{Si}$ with pyramids of $250 \mathrm{~nm}$ height and $180 \mathrm{~nm}$ in diameter and one film (C3) of $20 \mathrm{~nm}$ thickness was grown on porous Si. A more homogeneous material and a more uniform thickness were observed for thicker films. The details of the deposition system and typical deposition conditions were described elsewhere [2]. DLC thin films were amorphous, diamond thin films were composed from various size crystal accumulations.

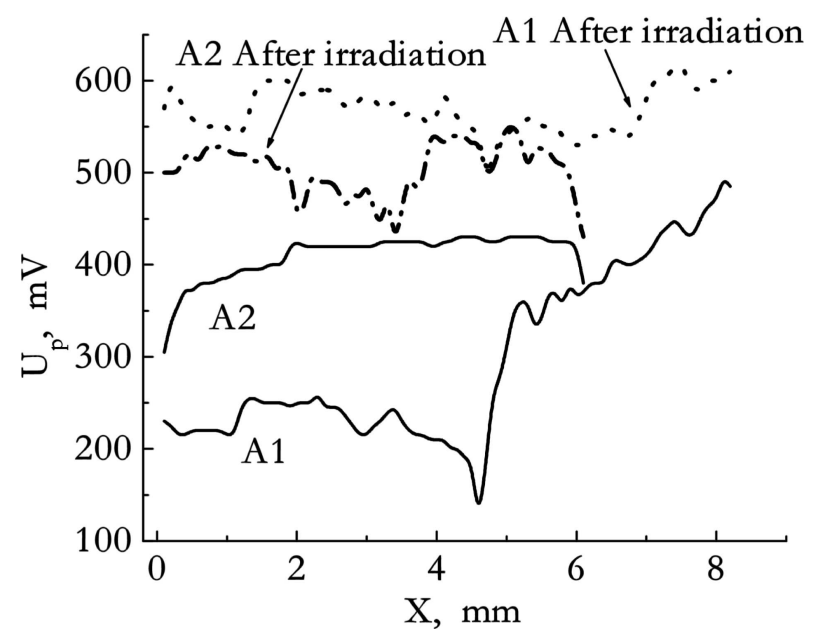

(a)

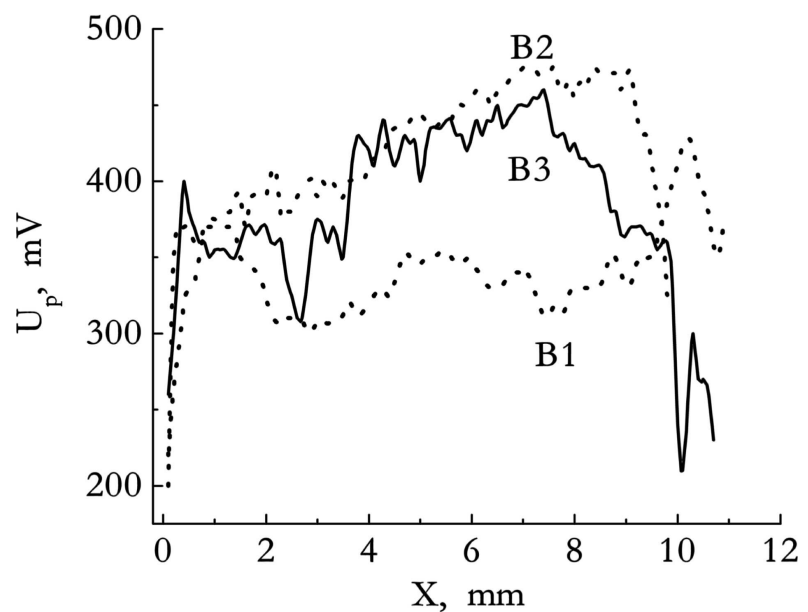

(b)

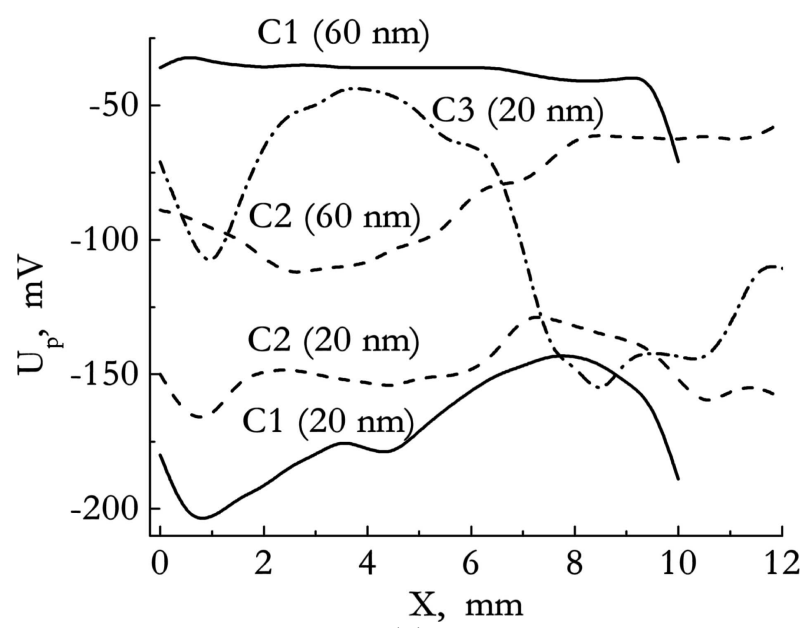

(c)

Fig. 1. Surface electric potentials of specimen groups (a) $A$, (b) $B$, (c) $C$.

\section{Investigation methods, experimental results, and discussion}

Surface energy levels of real semiconductor material form due to atoms adsorbed on surface or a lattice 
defect. These levels can be associated with acceptor, donor, electron, hole, recombination, or trapping centre and thus they can significantly change the properties of semiconductor structure. Obviously it was noticed that the surface energy levels influence surface properties. Generally it was seeked to create a positive electric charge on the surface in order to reduce the electron affinity (data about positive electron affinity is published, e.g., in [3]) and to improve conditions of the autoelectronic emission. Another way to improve autoelectronic emission was the creation of rough surface, for example by making pits and cones. Considerably stronger electric field is at cone tips (it lowers the height and the width of the barrier), and as a consequence the probability of electron tunnelling over the barrier is increased.

Generally electrical resistance of the investigated carbon films is high and usage of contact measurement methods is limited. Therefore we used a contactless

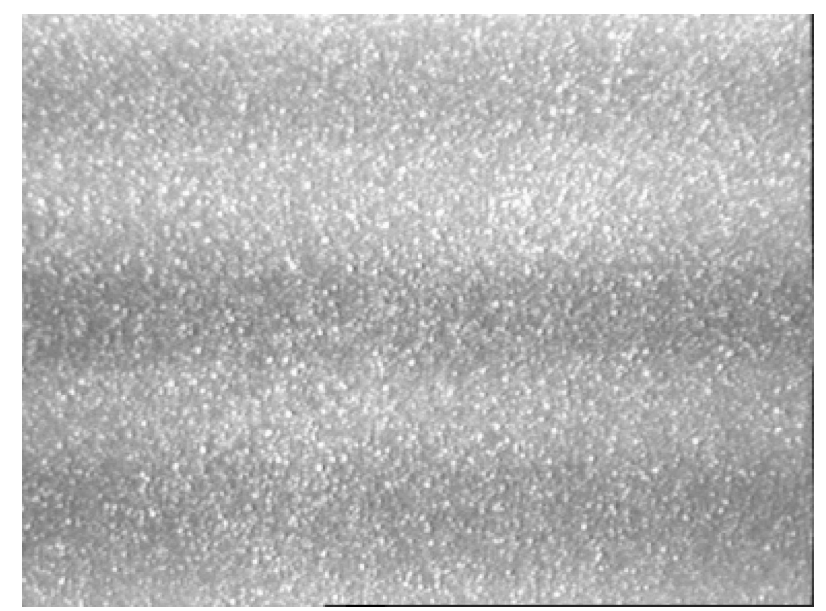

(a)

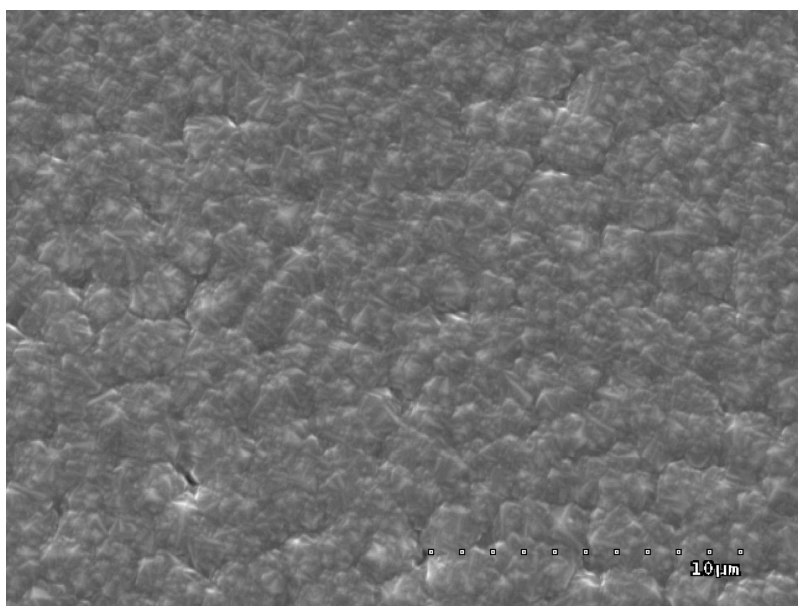

(c)
Kelvin-Zisman method [4]. The method's principle is that a probing microelectrode vibrates beyond investigated surface and the induced electric charge (proportional to electron work function) is converted into alternating voltage. Subsequent signal processing by electronic equipment and an introduced 100\% negative feedback enables one to optimize the metrological characteristics of measuring device and allows to determine the absolute value of specimen surface electric potential and its in-plane distribution (minimal sampling area diameter has been $10 \mu \mathrm{m}$ ). Microscopic investigation revealed a rough surface relief ("spotted") of examined specimens. We had measured the effective surface electric potential $\varphi_{\mathrm{ef}}$ :

$$
\varphi_{\mathrm{ef}}=\frac{1}{S} \int_{S} \varphi \mathrm{d} S=\varphi_{1} \frac{S_{1}}{S}+\varphi_{2} \frac{S_{2}}{S},
$$

where $S_{1}$ and $S_{2}$ are areas of pits and hillocks, $\varphi_{1}$ and $\varphi_{2}$ are corresponding surface potentials, $S=S_{1}+S_{2}$.

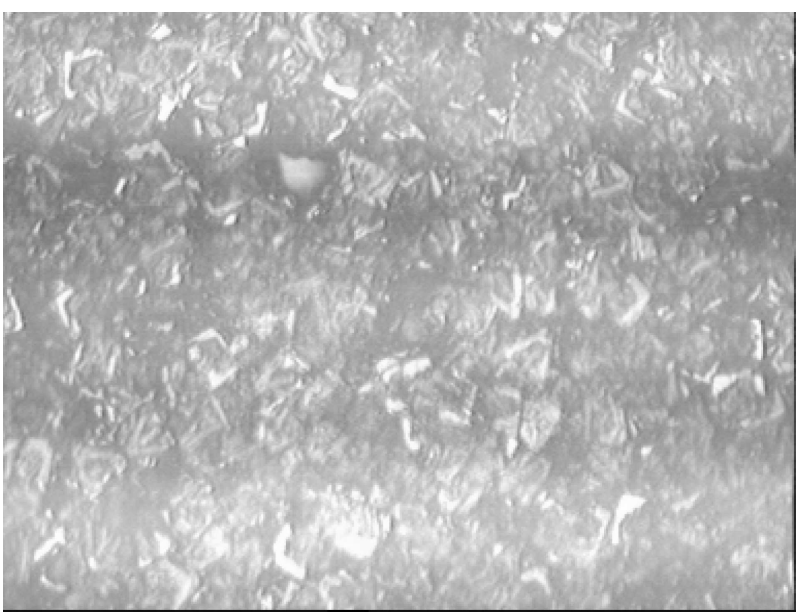

(b)

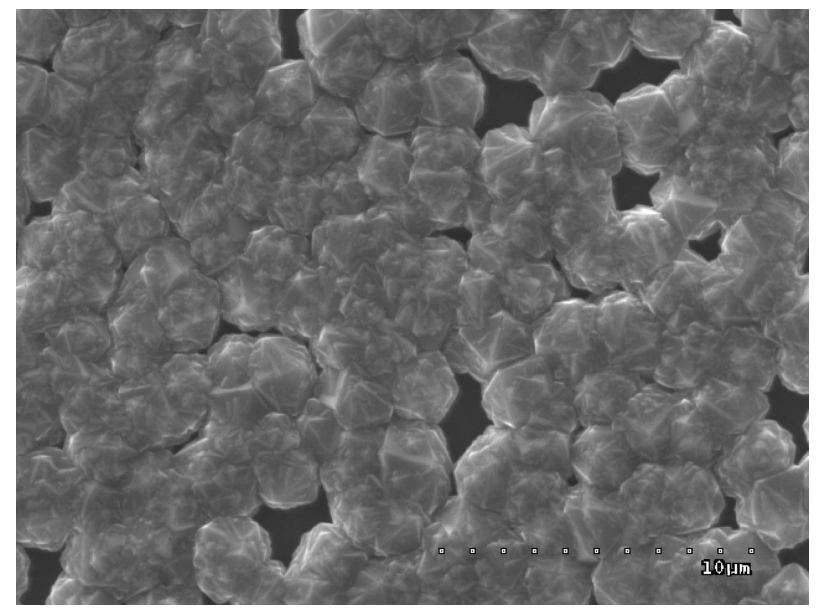

(d)

Fig. 2. Images of the investigated film surfaces: (a) specimen $A 1$ (magnification 50), (b) specimen $A 2$ (magnification 50), (c) specimen $B 2$, (d) specimen $B 3$. 
The surface potential is negative and its value corresponds to thermodynamic electron work function. Values of surface electric potential $U_{p}$ are measured with respect to the calibrated probe and are associated to effective surface potential as follows:

$$
-\varphi_{\mathrm{ef}}=\frac{W_{0}}{q}-U_{p}=-\varphi_{0}-U_{p},
$$

where $W_{0}$ is electron work function of probe, $q$ is electron charge.

According to the experimental results presented in Fig. 1(a-c), practically all specimens (except $C 1)$ are inhomogeneous. Additionally, surface electric potential of $A$ and $B$ groups of specimens was found to be independent of illumination with white light. Specimens of group $A$ were irradiated with $\alpha$-particles $\left({ }^{239} \mathrm{Pu}\right)$. A positive electric charge adsorbed on the surface of the specimens was detected. Therefore surface energy bands were bended downwards hereby improving autoelectron emission yield. According to the surface electric potential value and its distribution we state that the specimen $A 1$ is better than specimen $A 2$. The value of work function of specimen $A l$ is nearest to that of diamond. Figures $2(\mathrm{a}-\mathrm{d})$ show the images of the film surfaces. The surface of specimen $A l$ is the most uniform according to the presented specimen images.

The surface electric potential fluctuation observed for the $C$ group of specimens due to the white light irradiation was less than $50 \mathrm{mV}$, but the sign of the signal identified a negligible upward band bending. The values of electron work function of the mentioned group are higher for thicker films. It means that the properties of thicker DLC films are similar to those of diamond films. This result was partially confirmed by autoelectron emission investigation of the specimen $C 2$. The electron field emission behaviour of the film was characterized using a sphere-to-plane electrode configuration under UHV conditions at the pressure of $10^{-5} \mathrm{~Pa}$ in a special chamber. The distance between the electrodes was 7,14 , or $25 \mu \mathrm{m}$. Current-voltage characteristics were recorded using a $5 \mathrm{~mm}$ diameter stainless steel ball anode. The voltage in the range of 50-2500 V was applied between the electrodes during the emission measurements and was changed up and down several times in order to stabilize the $I-V$ curve. Current-voltage characteristics indicated that the autoelectron emission properties corresponded to the Fowler-Nordheim model [5].

\section{Conclusions}

Early studies of diamond and diamond-like carbon thin films (appointed to autoelectronic emission cathodes) deposited onto differently processed Si substrates by optical, electrostatic induction, and autoelectronic emission methods revealed:

- the films are non-uniform, exhibiting a distribution of in-plane values of surface electric potential;

- thicker diamond-like carbon films in group $C$ are characterized by better autoelectronic emission properties;

- broader data on the surface electric potential values of the same type films would give comprehensive information about availability of the films for autoelectronic emission cathodes.

\section{Acknowledgement}

The work was cofinanced by the Polish State Committee for Scientific Research (KBN), project No. 3 T11B 05026.

\section{References}

[1] K. Fabisiak, A. Banaszak, and M. Kaczamarski, Nucleation and growth of diamond films by using HF CVD technique, Functional Mater. 10, 117-120 (2003).

[2] Z. Haś and S. Mitura, Nucleation of allotropic carbon in an external electric field, Thin Solid Films 128, 353-360 (1985).

[3] J.E. Field, The Properties of Natural and Synthetic Diamond (Academic Press, London, 1992).

[4] S. Sakalauskas and A. Sodeika, Automatized measuring instrument of the surface electric potential and potential's distribution, Rev. Sci. Instrum. 69, 466-468 (1998).

[5] R.H. Fowler and L.W. Nordheim, Electron emission in intense electric fields, Proc. R. Soc. London, Ser. A 119, 173-181 (1928). 


\title{
DEIMANTO IR I JI PANAŠIU ANGLIES SLUOKSNIŲ ANT Si PADE்KLO PAVIRŠINIS POTENCIALAS
}

\author{
M. Dłużniewski ${ }^{\text {a }}$, T. Lozovski ${ }^{\mathrm{b}}$, R. Pūras $^{\mathrm{b}}, \mathrm{S}$. Sakalauskas ${ }^{\mathrm{b}}$ \\ ${ }^{\text {a } L o d z e ́ s ~ t e c h n i k o s ~ u n i v e r s i t e t a s, ~ L o d z e ́, ~ L e n k i j a ~}$ \\ ${ }^{\mathrm{b}}$ Vilniaus universitetas, Vilnius, Lietuva
}

\section{Santrauka}

Puslaidininkiniai sluoksniai vis plačiau taikomi autoelektroninès emisijos katodams gaminti. Tos emisijos metu katodai ikaista, todèl jiems gaminti geriau tinka plačiatarpès puslaidininkinès medžiagos, tokios kaip deimantiniai sluoksniai, pasižymintys dar ir labai dideliu šiluminiu laidumu, tuo padėdami lengviau optimizuoti pačią autoelektroninę emisiją.
Pateikti deimanto ir i deimantą panašių anglies sluoksnių, išaugintų ant i̇vairiai apdorotų silicio padéklų ir numatomų taikyti autoelektroninès emisijos katodams, pirminiai eksperimentiniai tyrimai, susiję su nesąlytiniu Kelvino ir Zismano (Kelvin-Zisman) būdu išmatuotomis išlaisvinimo darbų vertėmis arba vienareikšmiškai jas atitinkančiomis paviršinio elektrinio potencialo vertėmis, kurias lemia tiriamųjų sluoksnių paviršinès savybès. 